\title{
ВИКОРИСТАННЯ РЕЗУЛЬТАТІВ СУЧАСНИХ ДОСЛІДЖЕНЬ 3 ІСТОРІЇ МЕДИЦИНИ ДЛЯ ЕФЕКТИВНОГО РЕФОРМУВАННЯ ГАЛУЗІ ОХОРОНИ ЗДОРОВ'Я В УКРАЇНI
}

\author{
Л. М. Нечеглод
}

Черкаський медичний коледж

У статті проаналізовано останні дослідження з історіі охорони здоров'я. Виокремлено практичні рекомендації дослідників та обгрунтовано іх доцільність в реформуванні медичної сфери.

\section{USING THE RESULTS OF MODERN RESEARCH FROM THE HISTORY OF MEDICINE TO EFFECTIVE REFORM HEALTH CARE IN UKRAINE}

\author{
L. M. Nechehlod
}

Cherkasy Medical College

The article contains the analysis of the latest surveys in health care. The author shows practical suggestions of scientists and explains their necessity in medical sphere's reform.

Вступ. Сучасне українське суспільство продовжує всеохоплюючий процес ринкових трансформацій та децентралізації державного управління. Це багато в чому пояснює наростаючу кризу функціонування в різних сфрерах життя суспільства, до яких можна віднести й медицину. Система медичного обслуговування, що формувалась протягом радянського періоду, була пристосована до існуючої командно-адміністративної системи управління державою, яка існувала в СРСР. Однак після здобуття Україною незалежності, вона виявила свої недоліки в умовах ринкового суспільства. Оскільки охорона здоров'я є однією з найважливіших сфер життя суспільства, оптимізація діяльності медичних установ $€$ актуальною проблемою сучасного українського суспільства.

В останні роки історики почали активно студіювати проблеми охорони здоров'я України в різні періоди історичного розвитку. Особливий інтерес для нас складає період другої половини XIX - початку XX ст., адже в той час медицина отримала якісно новий рівень розвитку в існуючих умовах ринкового суспільства.

Основна частина. Важливим під час проведення реформ з управління, структуризації та визначенні джерел фінансування сучасної галузі охорони здоров'я в Україні є врахування досвіду функціонування подібних закладів у післяреформений період Російської імперіі. Автор ставить за мету проаналізувати праці істориків початку XIX ст. для виявлення ефективних шляхів розвитку медицини в ринкових умовах та 3' ясувати можливість їх практичного застосування в сучасних умовах.

Дослідник історії харківської медицини Ігор Робак, підводячи підсумки свого дисертаційного дослідження, дає конкретні пропозиції щодо його використання:

- створення опікунських рад у міських лікувальних закладах, склад яких призначався би відповідними радами (міськими і районними в містах) з числа найбільш впливових і шанованих у місті (районі) громадян для оперативного вирішення проблем

(C) Л. М. Нечеглод, 2014 
цих закладів, а також створення відповідної моральної атмосфери, в якій посада члена (голови) опікунської ради лікувального закладу вважалася 6 одним з найпочесніших громадських доручень у місті;

- вироблення муніципальними органами різних форм господарської і фінансової співпраці та взаємодопомоги з громадськими і приватними установами, що надають медичну допомогу населенню, створення в умовах хронічного дефіциту коштів спільних із міським самоврядуванням організаційно-господарських форм підприємств медичного профрілю на кшталт «Общества ночных дежурств врачей» або «Общества скорой медицинской помощи в г. Харькове»;

- відновлення прямих дотацій з місцевого бю джету для громадських лікувальних закладів з метою заохочення їх створення, як це було в дореволюційному Харкові;

- формування муніципальними органами спеціальних фінансових фондів, кошти яких витрачалися 6 виключно на конкретні цілі охорони здоров'я, і забезпечення неможливості їх нецільового використання;

- підпорядкування окремих підрозділів муніципальної міліції (коли вона буде створена) органам санітарного нагляду з метою рішучого припинення порушень санітарного законодавства, тобто створення так званої санітарної міліції на зразок міліції податкової;

- створення міським самоврядуванням громадських органів на кшталт «санитарных попечительств» задля вивчення санітарних проблем, здійснення санітарно-просвітницької роботи серед населення, залучення спонсорських коштів на санітарне впорядкування міста;

- введення державного медичного страхування, здійснення його на місцевому рівні (у розвиток ідеї «лікарняного збору») [1, с. 33-34].

Цікавим видається і досвід діяльності земств, як органів місцевого самоврядування, для забезпечення охорони здоров'я населення. Адже в наш час роль місцевого самоврядування стає вагомішим з кожним роком.

На думку Ольги Майстренко, саме активна робота земств сприяла розвитку галузі медицини, що дозволило досягти в Херсонській губернії вищого в Російській імперії рівня обслуговування населення і не відставати від загальносвітового [2, с. 18]. Водночас Надія Рубан відзначає, що земства, як інститут місцевого самоврядування, нерідко виправляли хиби загальнодержавних установ у галузі медицини, забезпечуючи ті ї̈ сфери, що виявлялися поза увагою центральної влади. Таким чином, досвід діяльності земств з організації охорони здоров'я необхідно використовувати й сучасним органам місцевого самоврядування та громадським організаціям. Останні $\epsilon$ особливо актуальними з огляду на розбудову громадянського суспільства, станом на 2009 р. зареєстровано в Україні 166 громадських лікарських організацій.

Василина Лещенко пропонує такі шляхи оптимізації діяльності громадських лікарських організацій щодо формування та реалізації державної політики України в галузі охорони здоров'я: сьогодні в Україні доцільною є спільна робота таких організацій у форматі національної ради з питань охорони здоров'я при Президентові України, дорадчої ради при комітеті Верховної Ради України 3 охорони здоров'я та громадської ради при Міністерстві охорони здоров'я (всеукраїнський рівень); одночасно на місцевому рівні необхідно активізувати створення громадських рад у галузі охорони здоров'я, основою яких можуть стати члени різних громадських лікарських організацій; необхідно прискорити роботу з перегляду та удосконалення нормативно-правової бази, зокрема прийняти закон України «Про лікарське самоврядування» $[4$, с. 17$]$.

Висновки. Аналізуючи останні дослідження 3 історії медицини, до яких віднесено дисертації дослідників: Ігоря Робака, Ольги Майстренко, Надії Рубан та Василини Лещенко. Роботи яких були захищені на початку XXI ст. Ми дійшли висновку, що сучасне студіювання різних аспектів історії медицини є більш методологічно виваженим. Не ставлячи під сумнів авторитет радянських вчених, зажатих у тісних методологічних та цензурних рамках. Відзначимо, що ї дослідження не могли почасти мати практичного значення для реалізації реформ медицини, оскільки тенденційно давали негативну оцінку дореволюційному досвіду організації охорони здоров'я населення. Сучасні дослідники використовуючи нові методологічні прийоми вийшли на якісно новий рівень в дослідженні історії медицини. Тому отримані результати, а особливо практичні рекомендації дослідників, які $є$ фахівцями з певних аспектів історії медицини необхідно обов'язково залучати до підготовки реформ у галузі охорони здоров'я. 
Корисними є й використання досвіду земств сучасними органами самоврядування та громадськими організаціями. Зростаючу роль останніх засвідчує дослідження Василини Лещенко. Відзначимо, що в організаційному аспекті ціннішим видається досвід дореволюційної, а не

\section{ЛITEPATУРA}

1. РобакІ. Ю. Історичні умови організації та специфіка розвитку охорони здоров'я в Харкові (XVIII - початок XX ст.) : автореф. дис. на здобуття наук. ступеня доктора іст. наук / І. Ю. Робак. - Київ, 2009-40 c.

2. Майстренко О. А. Роль Херсонського земства в медичному обслуговуванні населення у 1865-1917 рр. : автореф. дис. на здобуттянаук. ступеня канд. іст. наук / О. А. Майстренко. -Київ, 2009. - 23 с. радянської організації охорони здоров'я. Адже вона розвивалась в ринкових умовах, характерних і для сучасної України. В той час радянська система охорони здоров'я будувалась на зовсім інших принципах та засадах із домінуючою роллю держави.

3. Рубан Н. М. Розвиток земської медицини в Україні (1865-1914рр.) : автореф. дис. наздобуттянаук. ступеня канд. іст. наук / Н. М. Рубан - Донецьк, 2004. - 22 с.

4. Лещенко В. В. Громадські пікарські організації як суб'єкти формування та реалізації державноїполітики України в галузі охорони здоров'я : автореф. дис. на здобуття наук. ступеня канд. іст. наук / В. В. Лещенко. - Київ, 2009. -23 c.

Отримано 18.04.14 